\title{
Errata
}

To the paper

\section{SOME THEORETICAL ASPECTS OF THE USE OF ISOTOPIC EXCHANGE IN A HETEROGENEOUS LIQUID SYSTEM FOR RADIOCHEMICAL SEPARATIONS}

\author{
S. PALĀGYI
}

J. Radioanal. Chem. Vol. 21 (1974) 47-55.

On page 47 and 49 in the lines 5 and 14-15 from the bottom, respectively, "one-stage isotopic exchange" should read "one-stage separation procedure".

On page 50 and 51 in the lines 9 and 7, respectively, "one-stage" should read "multi stage". 